UDC 903.2(470.57):397

Submitted: 25.12.2019

LBC 63.4(2Poc.Баш)

Accepted: 29.04 .2020

\title{
SARMATIAN DAGGER COMPLEX FROM THE SURROUNDING AREA THE VILLAGE TOLBAZY IN THE SOUTHERN URALS
}

\author{
Nikita S. Savelev \\ Ufa Federal Research Center of the Russian Academy of Sciences, Ufa, Russian Federation \\ Sergey Yu. Nikolaev \\ Ufa Federal Research Center of the Russian Academy of Sciences, Ufa, Russian Federation
}

\begin{abstract}
Prokhorov culture (III-II centuries BC), found in different years in the vicinity of the village of Tolbazy located in the forest-steppe of the Southern Urals (Republic of Bashkortostan, Aurgazinsky district) are published. It is shown that according to physical and geographical data, this area (about $15 \times 15 \mathrm{~km}$ ) is allocated to a single microdistrict located at the crest of the Bielsko-Urshak watershed, which has a width of more than $50 \mathrm{~km}$ at this point. The territory of the microdistrict is elevated (100 meters or more from the foot of elevation, 250 meters above sea level on average), it abounds with small lakes and springs on the top, with the sources of small watercourses on the slopes and it is surrounded by rivers on all sides. Most of the findings were made on the plateau or at the sources of small watercourses, some of them - in river valleys. It is concluded that this area can be considered as a separate honey cell, "nomadic parish" or summer dwelling complex, which is typical for the settlement system of early nomads to the north of the hills of Obshchiy Syrt. The nearest known honey cells are located at a distance of 5-12 km from Tolbazinsky district and the number of finds of bladed weapons of the mid-late I Millennium BC varies from 3-4 to 25 pieces. It is also shown that in the III-II centuries BC, the development of bladed weapons (swords and daggers with a straight cross quillion and a crescent-shaped pommel) among the nomads followed the line of standardization of earlier forms of the Southern Urals, the assimilation of individual innovations and imitation of samples with a ring-shaped pommel representing foreign culture for the region.
\end{abstract}

Key words: Southern Urals, early nomads, Scythian-Sarmatian time, Prokhorov culture, stray finds, daggers, resettlement system.

Citation. Savelev N.S., Nikolaev S.Yu., 2020. Sarmatian Dagger Complex from the Surrounding Area the Village Tolbazy in the Southern Urals. The Lower Volga Archaeological Bulletin, vol. 19, no. 1, pp. 149-166. (in Russian). DOI: https://doi.org/10.15688/nav.jvolsu.2020.1.8

УДК 903.2(470.57):397

ББК 63.4(2Рос.Баш)

Дата поступления статьи: 25.12.2019

Дата принятия статьи: 29.04.2020

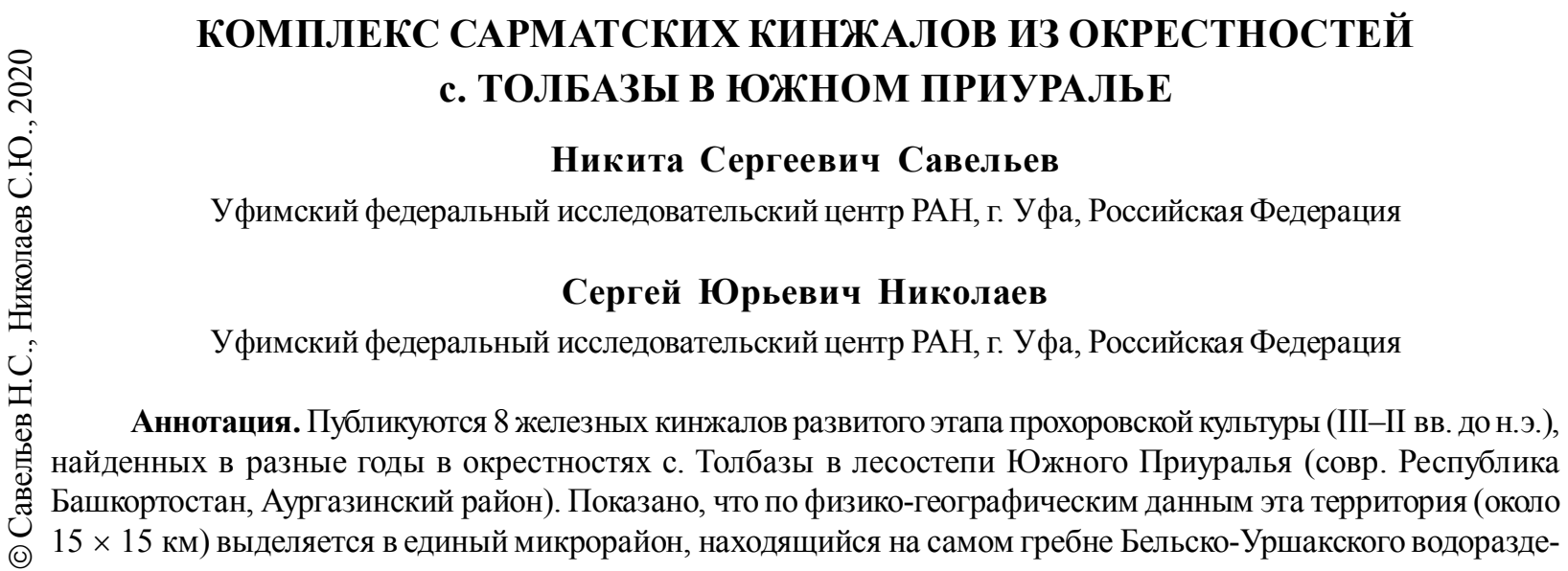


ла, имеющего здесь ширину более 50 км. Территория микрорайона возвышенная (100 и более метров от подножья, в среднем 250 м над уровнем моря), изобилует небольшими озерами и родниками на вершине, истоками малых водотоков на склонах и со всех сторон окружена реками. Большинство находок сделано на плато или у истоков малых водотоков, часть - в речных долинах. Сделан вывод о том, что данная территория может рассматриваться как отдельная сота, «кочевая волость» или летовочный комплекс, что характерно для системы расселения ранних кочевников к северу от возвышенностей Общего Сырта. Ближайшие известные соты расположены на расстоянии 5-12 км от Толбазинского микрорайона и количество находок клинкового оружия середины - конца I тыс. до н.э. варьирует от 3-4 до 25. Также показано, что в III-II вв. до н.э. у кочевников Южного Урала развитие клинкового оружия (мечи и кинжалы с прямым перекрестьем и серповидным навершием) шло по линии стандартизации более ранних форм, усвоения отдельных инноваций и подражания инокультурным для данного региона образцам, имеющим кольцевидное навершие.

Ключевые слова: Южный Урал, ранние кочевники, скифо-сарматское время, прохоровская культура, случайные находки, кинжалы, система расселения.

Цитирование. Савельев Н. С., Николаев С. Ю., 2020. Комплекс сарматских кинжалов из окрестностей с. Толбазы в Южном Приуралье // Нижневолжский археологический вестник. Т. 19, № 1. C. 149-166. DOI: https://doi.org/10.15688/nav.jvolsu.2020.1.8

\section{Памяти Р.Б. Исмагилова (1949-2014)}

Благодаря целенаправленным исследованиям ряда уральских археологов последних десятилетий и, в первую очередь, Р.Б. Исмагилова, было установлено, что лежащие к северу от возвышенностей Общего Сырта степные и лесостепные пространства Южного Приуралья на фоне всех окружающих территорий выделяются очень большим количеством находок (так называемых «случайных») мечей и кинжалов скифо-сарматского времени. За это время количество только введенных в научный оборот находок составляет не менее 300 [Исмагилов, 1978; 1980; 2001; Исмагилов, Скарбовенко, 1977; Обыденнов, Савельев, 1994; и др.]. Картографирование большей части из них позволило проследить, что все они сконцентрированы в пределах треугольника Уфа - Белебей - Исянгулово (около $150 \times 280$ км), достаточно четко разделяясь на три территориальные группы (водораздельный гребень Бугульминско-Белебеевской возвышенности, Бельско-Уршакское междуречье к северу от Стерлитамака и зажатая между хребтом Малый Накас и Уральскими горами долина р. Большой Ик [Савельев, 2016, с. 244, рис. 1].

К сожалению, длительная болезнь и безвременная кончина Р.Б. Исмагилова не позволили ему в полной мере опубликовать и систематизировать все многочисленные находки мечей и кинжалов, данные о которых собирались им и его коллегами по самым разным музеям (районным, школьным, деревенским) в основном на территории Башкирии. Долгие годы среди коллег считалось хорошим тоном при возвращении из какой-нибудь разведки привезти Р.Б. Исмагилову в подарок зарисовку хотя бы одного клинка, найденного в ближайшем музее. В настоящее время значительный по размеру архив Р.Б. Исмагилова разбирается и систематизируется в ИИЯЛ УФИЦ РАН. Уже ясно, что выполнение этой работы, с одной стороны, позволит ввести в научный оборот достаточное количество до сих пор неопубликованных экземпляров, с другой - уточнить и значительно расширить данные по местам и условиям нахождения многих ранее опубликованных мечей и кинжалов. В ряде случаев обращение к архивным материалам позволяет увидеть детали, не отмеченные в старых публикациях. Чаще всего к ним относятся сечения, профилировка, особенности сломов, детализация наверший и перекрестий.

В настоящей статье публикуются данные по восьми кинжалам, найденным в приуральской лесостепи, в 75 км к югу от г. Уфа и в 45 км к северу от г. Стерлитамак, в средней части Бельско-Уршакского водораздела, имеющего здесь ширину более 50 км, практически на его гребне ${ }^{1}$. Ранее отмечалось, что участок Толбазы-Уфа протяженностью около 80 км является вершиной треугольника Уфа - Белебей - Исянгулово, в которой и сосредоточено абсолютное большинство «случайных» находок клинкового оружия, при этом особенностью именно этой территории явля- 
ется полное отсутствие экземпляров савроматского времени [Савельев, 2016]. Все публикуемые находки сделаны в небольшом (около $15 \times 15$ км) микрорайоне с условным центром в с. Толбазы (райцентр Аургазинского района Республики Башкортостан), ограниченном со всех сторон реками, относящимися к бассейну р. Уршак (с севера и востока это p. Аургазы, с запада - p. Турсугали, с юга p. Таши). Территория безлесая, степная, в настоящее время практически полностью распахана, изобилует родниками, истоками сезонных водотоков и запрудами на них. Небольшие лесные массивы приурочены исключительно к возвышенным местам с истоками водотоков.

Топографически могут быть выделены две группы находок: условно «вершинная», приуроченная к вершине водораздельного плато в окрестностях д. Юламаново (5 кинжалов), и «речная», связанная с долиной р. Турсугали и ее притоком - p. Таши (рис. 1).

\section{Юламановская группа}

Современная д. Юламаново расположена на вершине водораздела рек Аургазы и Чиганлы - правого притока р. Турсугали (рис. 2). Высота места расположения этого населенного пункта над р. Аургазы, протекающей в 6 км к северу, - более 100 м (около 250 м над уровнем моря). На территории деревни и к западу от нее расположено 3 кургана Юламановского могильника, один из которых был исследован в 1934 г. М.С. Касьяновым [Археологическая ..., 1976, с. 114, № 914]. Данные об этих раскопках не сохранились, но, судя по топографии и внешнему виду насыпей, могильник относится к скифосарматскому времени.

Из пяти публикуемых кинжалов три вводятся в научный оборот впервые.

1. Железный кинжал найден в 1975 г. в 1,2 км к югу-юго-западу от д. Алексеевка и в 2,7 км западнее д. Юламаново, на западном краю колхозного сада, при сборе сена [Исмагилов, 2001, с. 123, 140, табл. VII,71]. Хранился в Юламановской средней школе, где и был зарисован Р.Б. Исмагиловым (ноябрь 1977 г.). Общая длина кинжала 49,5 см, сохранился полностью (рис. 3,1). Навершие серповидное, изогнуто под углом $130^{\circ}$, в сечении круглое, его длина 8 см, диаметр дрота 0,7-0,9 см. Рукоять прямоугольная в сечении, с немного дуговидными торцами и вогнутыми широкими плоскостями. Длина рукояти 7,4 см, ширина 1,3-1,7 см, к навершию незначительно сужается. Перекрестье брусковидное, чуть согнуто в сторону клинка, слегка сужается от середины к концам, в сечении прямоугольное. Длина перекрестья 8 см, ширина 0,9 см в середине, 0,6 см к концам, толщина 1,1 см. Форма клинка вытянуто-треугольная, сечение ромбическое, длина 40,3 см, ширина возле перекрестья 4,5 cм, максимальная толщина 0,7 см.

Место находки приурочено к верхней части склона сырта в сторону р. Аургазы с несколькими небольшими озерами и запрудами на истоках начинающихся здесь как минимум трех малых водотоков. Судя по схеме, составленной Р.Б. Исмагиловым (рис. 3,6), данная территория имела местное устойчивое наименование - Елей-Джайляу, что с башкирского языка может быть переведено как «хорошая летовка». Показательно, что на схеме также присутствует и указание на расположение выше по склону, где-то рядом с долиной р. Чиганлы, некого «Ногайского места», что также может быть связано со средневековыми кочевьями.

2. Железный кинжал найден возле ныне не существующей д. Куганак на р. Чиганлы, в 1 км юго-западнее д. Юламаново Аургазинского района Республики Башкортостан [Исмагилов, 2001, с. 123, 139, табл. VI,54] 22. Хранился в Юламановской средней школе, где в ноябре 1977 г. был зарисован Р.Б. Исмагиловым. Общая длина кинжала 32,2 см, сохранился полностью (рис. 3,2). Навершие серповидное, изогнуто под углом $130^{\circ}$, длина $7,2 \mathrm{~cm}$. В центре навершия сечение дрота овальное $(7 \times 4,5$ мм), края на длину 1,3 см расплющены в лопасти шириной 11 мм и толщиной 2 мм. Рукоять в сечении ромбическая, ее длина 8 см, ширина 1,3-1,6 см с максимальным расширением в средней части. Перекрестье брусковидное, немного изогнуто в сторону клинка, его длина 6,4 см, ширина 0,7 см. Форма клинка вытянуто-треугольная, сечение ромбическое, общая длина $23 \mathrm{~cm}$, максимальная толщина 0,5 см. Ширина клинка возле перекрес- 
тья 4,3 см, практически сразу дуговидно сужается на 0,5 см с каждой стороны (следы заточки?). С обеих сторон клинка по центральному ребру проходит узкий прорезанный дол общей длиной 17,4 см. Дол начинается в 0,3 см от перекрестья и не доходит до кончика клинка $5 \mathrm{~cm}$.

3. Железный кинжал хранился в школьном музее д. Юламаново Аургазинского района Республики Башкортостан, где в сентябpe 2004 г. был зарисован Р.Б. Исмагиловым. Происходит из окрестностей населенного пункта, более точные данные отсутствуют. Общая длина кинжала $33 \mathrm{~cm}$, кончик клинка отсутствует (рис. 3,3). Навершие серповидное, с одной стороны обломлено, длина сохранившейся антенны 3,2 см, немного изогнута наружу, сечение дрота круглое. Рукоять в сечении ромбическая, ее длина 7,5 cм, ширина 1,21,7 см, плавно расширяется к перекрестью. Перекрестье прямое, длиной 5,8 см, шириной 0,7 см. Клинок вытянуто-треугольный, линзовидный в сечении. Сохранившаяся длина клинка 24,1 см (первоначально - не более 25 25,5 см), ширина возле перекрестья 3,9 см, возле обломанного кончика - 0,5 cм, максимальная толщина 0,5 см. От перекрестья с обеих сторон клинка на длину 18,5 см идут по два дола. Публикуется впервые.

4. Железный кинжал хранился в школьном музее д. Юламаново Аургазинского района Республики Башкортостан, где в сентябpe 2004 г. был зарисован Р.Б. Исмагиловым. Происходит из окрестностей населенного пункта, более точные данные отсутствуют. Общая длина кинжала 34 см, навершие не сохранилось - оно обломано с обеих сторон от рукояти (рис. 3,4 ). Рукоять прямая, ее длина 7,3 см, ширина 1,2 см, в сечении - уплощенный с торцов овал, толщина в середине $0,7 \mathrm{~cm}$, с боков - 0,4 см. Перекрестье прямое, длиной 5,3 см, шириной 0,7 см. Клинок вытянутотреугольной формы, ромбический в сечении, его длина $25,1 \mathrm{~cm}$, толщина в месте сечения 0,6 см. Публикуется впервые.

5. Железный кинжал найден весной 1997 г. в 1 км к юго-западу от окраины с. Толбазы, возле автодороги в сторону Уршака, при выравнивании участка под коллективные сады. Территория равнинная, является вершиной водораздела (около 275 мБС), примерно от этого места в разные стороны отходят истоки малых водотоков, в крупном лесном массиве, расположенном юго-восточнее, находится несколько озер диаметром от 30-50 до 100 м. Найденный кинжал сохранился полностью, его общая длина 32,8 см (рис. 3,5). Навершие кольцевидное, насаженное на рукоять, размером 4,6 $65,3 \mathrm{~cm}$, круглое в сечении, диаметром 0,4 см в верхней части, с утолщением до 0,7 см в нижней части и до 1,0 см в месте крепления к рукояти. Рукоять прямая, в сечении прямоугольно-округлая, ее длина 7,5 см, ширина 1,1 см, толщина 0,7 см. Перекрестье брусковидное, длиной 6 см, прямое со стороны клинка и немного выпуклое со стороны рукояти, ширина в середине $0,9 \mathrm{~cm}$, с краев - 0,7 см. Клинок вытянуто-треугольный, ромбический в сечении, с одним прорезанным узким долом по оси с каждой стороны. Длина клинка $20 \mathrm{~cm}$, максимальная ширина $3,9 \mathrm{~cm}$, толщина без долов 0,6 см. Долы начинаются в 0,3 см от перекрестья, имеют длину 13,2 см, то есть в нижней трети клинка они отсутствуют. Публикуется впервые.

\section{Группа Турсагали - Таши}

Расположена в 8-9 км к югу от д. Юламаново, на южной границе микрорайона. Два кинжала найдены на р. Турсагали, в соседних населенных пунктах - Турсагали и Таштамак, расстояние между местами находок не превышает 2,5-3,5 км, третий происходит из д. Балыклыкуль, отстоящей на 4-5 км к востоку и расположенной на истоках небольшой p. Таши, спускающейся с вершины водораздела. Высоты поверхности около н.п. Турсагали и Таштамак - 148-160 м над уровнем моря, в д. Балыклыкуль - около 220 м. Самая высокая точка всей территории, условно объединяемой в «Толбазинский микрорайон»287,8 мБС, расположена в 2 км к северо-востоку от д. Балыклыкуль и не более чем в 33,5 км к югу от места находки описанного выше кинжала с окраины с. Толбазы.

6. Железный кинжал хранился в школьном музее д. Балыклыкуль, где в сентябре 2003 г. был зарисован Р.Б. Исмагиловым. Происходит из окрестностей населенного пункта, более точные данные отсутствуют. Публикуется впервые. Общая длина кинжала 
33 см, кончик клинка обломан (рис. 4,1). Навершие серповидное, изогнуто под углом $160^{\circ}$, одна антенна частично обломлена, длина второй $3,8 \mathrm{~cm}$, первоначальная длина навершия около 8,5 см. Сечение антенн у рукояти многогранное, к окончаниям становится более округлым, толщина дрота $0,5-0,8$ см. Рукоять в сечении ромбическая, со слегка дуговидными гранями, ее длина 7,8 см, максимальная толщина 1,2 см, ширина 1,2-1,7 см, плавно расширяется к перекрестью. По всей длине рукоять покрыта поперечными насечками, вероятно, имитирующими обмотку. Перекрестье прямое, длиной 6,4 см и шириной $1 \mathrm{~cm}$. Клинок вытянуто-треугольный, с незначительным плавным сужением в верхней трети и значительно более резким сужением на остальной длине. Сечение клинка ромбическое, длина без обломанного кончика 23,6 см, максимальная толщина 0,6 см, ширина возле перекрестья 4,5 см. От него по обеим сторонам клинка на длину 17,8 см идут пологие линзовидные в сечении долы глубиной не более 2-3 мм. Ширина долов у перекрестья $0,7-0,8$ см, далее резко расширяются до 1,3-1,4 см и после этого плавно сужаются параллельно лезвиям клинка. Наличие широких долов и дополнительная проковка кромки сформировали с каждой стороны клинка по три ребра жесткости, что является одним из характерных признаков для части «классических» прохоровских мечей и кинжалов [Овсянников, Савельев, 2019, c. 209-210].

7. Железный кинжал найден в 1976 г. в 0,3 км южнее д. Таштамак Аургазинского района Республики Башкортостан, за рекой Турсагали (возможно, на ее левом, более пологом берегу), на пашне во время рекультивации [Исмагилов, 2001, с. 126, 145, табл. ХII,132]. Хранился в Таштамакской средней школе, где в марте 1978 г. был зарисован Р.Б. Исмагиловым. Общая длина кинжала 42,3 см, навершие не сохранилось, оно полностью обломано с обеих сторон от рукояти (рис. 4,2). Рукоять прямоугольная в сечении, ее длина $7,3 \mathrm{~cm}$, ширина 0,9-1,1 см, к перекрестью расширяется до 1,6 см, толщина 0,7 см. Перекрестье прямое, длиной $6 \mathrm{~cm}$, толщиной $0,7 \mathrm{~cm}$. Длина клинка 33,5 см, сечение ромбическое, в верхней трети лезвия параллельны, далее форма клинка вытянуто-треугольная. Ширина клин- ка возле перекрестья 3,1 см, максимальная толщина $0,8 \mathrm{~cm}$.

8. Железный кинжал найден в д. Турсугали Аургазинского района Республики Башкортостан [Исмагилов, 2001, с. 124, 142, табл. IX,94]. Хранился в Таштамакской средней школе, где в 1975-1976 гг. был зарисован Р.Б. Исмагиловым. Немного позднее, в марте 1978 г. этот кинжал в школьном музее уже отсутствовал. Общая длина кинжала 31,7 см (рис. 4,3 ). Навершие серповидное, изогнуто под углом $130^{\circ}$, одна антенна обломана, длина второй 5,0 см, первоначальная длина навершия около $11 \mathrm{~cm}$. Сечение антенн округлое, толщина дрота 0,6 см. Рукоять в сечении прямоугольная, сильно уплощенная, толщиной $0,3 \mathrm{~cm}$. Длина рукояти 7,8 см, ширина 1,7 см в середине, плавно расширяется (до 2-2,3 см) к навершию и перекрестью. Перекрестье прямое, его длина 5,2 см, ширина 0,4 см. Длина клинка $22,4 \mathrm{~cm}$, максимальная толщина $0,7 \mathrm{~cm}$, ширина возле перекрестья 3,4 см, сечение ромбическое. Лезвия у клинка параллельные, у острия резко сужаются.

За исключением кинжала с кольцевидным навершием из Толбазов (рис. 3,5 ), все остальные по видимому сходству могут быть связаны с сильно стандартизированным клинковым оружием развитого (классического) этапа прохоровской культуры. Однако рассмотрение деталей и их связанности друг с другом позволяет разделить всю анализируемую выборку на две группы - условно раннюю и условно позднюю, каждая из которых включает по 4 экземпляра.

К ранней группе относятся один клинок из Юламаново (рис. 3,3), клинки из Алексеевки, Куганака и Балыклыкуля (рис. 3,1,2, 4,1). Для них характерен комплекс признаков клинкового оружия развитого этапа прохоровской культуры: прямое перекрестье, серповидное навершие и относительно широкий вытянутотреугольный клинок ромбического сечения. Также к ним необходимо отнести ромбическое сечение рукояти, так как только у экземпляра из Алексеевки рукоять в сечении прямоугольная, с немного дуговидными торцами и вогнутыми широкими плоскостями. Подобные «двутавровые» рукояти генетически восходят к оружию предшествующего, савроматского и переходного, времени и наиболее распрост- 
ранены именно в лесостепи и частично в степи Южного Приуралья [Федоров, 2013, рис. 7]. Для абсолютного большинства сложившихся прохоровских мечей и кинжалов характерно именно ромбическое сечение рукоятей [Хазанов, 1971, с. 6; Исмагилов, 2001, с. 119].

Несмотря на незначительные утраты, все навершия могут быть четко отнесены к серповидной форме, только в одном случае - для кинжала из Куганака (рис. 3,2) - можно говорить о более рожковидной (рогатковидной) форме. Также его особенностью является расковка окончаний навершия в тонкие лопасти. Этот прием неоднократно зафиксирован на прохоровских клинках лесостепи Южного Приуралья, в том числе и среди находок, сделанных в непосредственной близости от территории Толбазинского микрорайона [Горбунов, Исмагилов, 1976, рис. 2,13,19,21,22,24; Исмагилов, 2001, табл. IV,36,37, V,42,44, VI,51,53,56,59, VIII,78]. Судя по утонченности и прямоугольному сечению рукоятей у основного количества клинков с лопастевидной расковкой наверший, данный прием является относительно более поздним вариантом оформления эфеса прохоровских мечей и кинжалов.

На кинжале из Балыклыкуля присутствует крайне редкая деталь - рифление рукояти короткими перпендикулярными насечками. Среди всего прохоровского клинкового оружия подобное рифление известно еще только на одном экземпляре - кинжале из Куезбашево, найденном всего в 15 км к северо-востоку [Исмагилов, 2001, с. 122, 138, табл. V,48; Николаев, 2019, рис. 2,1]. Несомненно, что это рифление должно рассматриваться как некое подражание обмотке рукояти кожаным ремешком, широко известной у кочевников региона второй половины - конца I тыс. до н.э. [см. напр.: Садыкова, Васильев, 2001, с. 58, 75, рис. 7,3; Самашев и др., 2007, с. 233-235, 243; Яблонский, 2010 , с. 54,169 , рис. 73,3$]$. Учитывая ритуальное использование мечей и кинжалов, зафиксированных впоследствии в качестве «случайных» находок [Савельев, 2016; 2018] и крайнюю редкость рифления рукояти, данная деталь может быть выведена из практики декорирования «парадных» прохоровских кинжалов [Мордвинцева, Шинкарь, 1999]. Ближайшей аналогией может рассматриваться кинжал из погр. 2 кург. 17 могильника Покровка-2 (II-І вв. до н.э.), рукоять которого была обложена золотым листом с рифлеными перпендикулярными поясками [Яблонский, 1998, с. 100, рис. 6,3; Куринских, 2012, с. 78].

За исключением короткого меча из Алексеевки, на клинках всех остальных кинжалов ранней группы присутствуют долы. Если узкие - в основном одиночные - треугольного сечения долы (рис. $3,2,5$ ) достаточно распространены на мечах и кинжалах с серповидным (и производными от него) и кольцевидным навершиями, то широкие парные долы (рис. 3,3, 4,1) встречаются исключительно на оружии прохоровского типа. Р.Б. Исмагилов посчитал необходимым выделить их в особую серию «кинжалов с гофрированными клинками», включающую в себя 17 экземпляров [Исмагилов, 2001, с. 120] ${ }^{3}$. Именно для этой группы характерны наиболее широкие треугольные клинки, в ряде случаев сочетающиеся с плавным расширением в верхней трети или даже в середине клинка [Исмагилов, 2001, №№22, 35, 38, 39, 41, 48, 95, 124]. В очень смягченном виде эта особенность присутствует и на кинжале из Балыклыкуля. Еще одной особенностью «кинжалов с гофрированными клинками» является очень узкое, массивное (порой даже утолщенное), ромбическое в сечении острие клинка, более похожее на жало.

Анализ признаков данной группы показал, что Р.Б. Исмагилов в нее включал только клинки с широкими дуговидными долами. Одним из авторов недавно было показано, что формировались эти долы путем проковки наложенных с обеих сторон клинка и жестко зафиксированных на нем четырех цилиндрических шаблонов. Это и последующая дополнительная проковка кромки сформировали с каждой стороны клинка по три ребра жесткости, что является одним из характерных признаков описанной выше части «классических» прохоровских кинжалов [Овсянников, Савельев, 2019, с. 209-210]. Вероятно, первоначальной задачей данного технологического приема являлось создание нервюры (ребра жесткости) по центру клинка, так как экземпляры с выделенным проковкой ребром начинают встречаться еще в савроматское время [Смирнов, Петренко, 1963, табл. 11,4,11,21]. 
Наряду с клинками с дуговидными долами, на кинжалах, а также мечах (!) прохоровского времени встречаются парные широкие треугольные в сечении долы, имеющие длину от $1 / 2$ до $3 / 4$ клинка. В настоящее время их известно более 20 [Горбунов, Исмагилов, 1976, рис. 2,13,14,21, 3,27,37; Обыденнов, Савельев, 1994, рис. 2,5,13, 3,28; Исмагилов, 2001, №31, 50-53, 57, 58, 97, 98, 126, 144; Краева и др., 2008, рис. 1,3; Яблонский, 2010, с. 39, рис. $41,9,10$; Таиров, 2018 , рис. 4,6$]$. Прямое родство широких треугольных и широких дуговидных долов несомненно. Отличия - в значительной «компактности» центральной декорированной части клинка на экземплярах с треугольными долами, в основном стройной широкотреугольной форме клинка (описанные выше расширения клинков встречаются единично [Горбунов, Исмагилов, 1976, рис. 2,13; Таиров, 2018, рис. 4]), наличии треугольных долов также и на экземплярах с кольцевидным навершием и рукоятью прямоугольного сечения [Горбунов, Исмагилов, 1976, рис. 2,21; Исмагилов, 2001, № 100, 110, 112], а также тенденцией превращения этих долов в узкие канавки. Перечисленные признаки показывают, что мечи и кинжалы с треугольными долами являются поздним вариантом рассмотренной выше «гофрированной» группы.

Происхождение кинжалов с «гофрированным» клинком пока не установлено. Можно только сказать, что на Южном Урале, в Волго-Уральском регионе и Урало-Казахстанских степях какие-либо прототипы для оружия данной группы не известны и она может рассматриваться как яркая инновация. При этом, исходя из опубликованных фотографий, на широком треугольном клинке парадного меча из кург. 1 могильника Филипповка-1 присутствовали широкие дуговидные долы и выделенная в центре нервюра [Золотые..., 2001, кат. 6; Коллекции..., 2018, кат. 833]. К сожалению, единственный рисунок этого меча [Пшеничнюк, 2012, рис. 27,1] очень схематичен и не передает многих важных деталей, поэтому его использование в качестве полноценного источника пока невозможно. Судя по наличию различающегося только деталями ядра (широкий треугольный клинок, широкие дуговидные долы, граненое жало на окончании клинка, ромбическая в сечении рукоять, частое рас- ширение клинка в верхней части) и множеству самых различных «реплик» и «цитат», данная инновация в Южном Приуралье начала активно использоваться в качестве образца для подражания и сформировала локальную моду на «гофрирование» клинка. По имеющимся данным, время ее существования - от самых ранних образцов с прорезной, двухтавровой и трехчастной рукоятью [Исмагилов, 2001, № 22, 31, 34, 35] до наиболее поздних с кольцевым навершием, где долы превратились уже в узкие канавки [Исмагилов, 2001, № 100, 107-110, 112] - может быть ограничено III-II вв. до н.э.

К условно поздней группе относятся второй клинок из Юламаново (рис. 3,4 ), кинжалы из Толбазов, Таштамака и Турсугали (рис. 3,5 , $4,2,3)$. Экземпляры из Юламаново и Таштамака отличаются ромбическим в сечении узким треугольным клинком и узкой овальной (рис. 3,4 ) и прямоугольной (рис. 4,2 ) в сечении рукоятью. Навершие в обоих случаях отломлено у основания. Ориентируясь на сечение и зауженность рукояти, можно предполагать, что навершие могло быть как серповидной (со всеми возможными вариациями) [Горбунов, Исмагилов, 1976, рис. 2,22,23; Исмагилов, 2001, № 72-85], так и кольцевидной (или в виде разомкнутого кольца) [Исмагилов, 2001, № 102-114] формы. В этом отношении может быть важно, что на кинжалах с серповидным навершием при узкой неромбической рукояти и относительно узким вытянутым клинком никогда не встречаются ни долы, ни узкие канавки, а на кинжалах с кольцевидным и разомкнуто-кольцевидным навершием они известны [Исмагилов, 2001, № 101, 103, 107$110,112]$. Одним из подобных, отличающимся только немного более широким треугольным клинком, является кинжал с наваренным кольцевидным навершием, найденный около с. Толбазы (рис. 3,5). Исключая форму навершия, он не может быть выведен за пределы условно поздних образцов прохоровских кинжалов (см. напр.: [Исмагилов, 2001, № 70]).

Последний кинжал поздней группы происходит из д. Турсугали (рис. 4,3). От всех описанных выше он отличается тонкой пластинчатой рукоятью, тонким плоским перекрестьем, клинком с параллельными лезвиями и очень большим (около $11 \mathrm{~cm}$ ) серповидным 
навершием. За исключением последнего элемента все остальные детали характерны для клинков среднесарматского времени или, точнее, имеющих кольцевидное навершие [Хазанов, 1971, с. 5-6; Горбунов, Исмагилов, 1976, c. 244-245]. Исходя из длины перекрестья $(5,2$ см), размеров и пропорций кинжала данное навершие может быть названо гипертрофированным.

Подобное удлиненное навершие встречается на двух группах кочевнического клинкового оружия. Первая из них - кинжалы, которые по основным признакам (параллельные лезвия, пластинчатая или узкая рукоять) аналогичны рассматриваемому турсугалинскому [Обыденнов, Савельев, 1994, рис. 2,6, 3,21,23; Исмагилов, 2001, № 84]. Навершие последнего кинжала загнуто в полукруг, в остальных случаях их длина варьируется в пределах 9,511,5 см. Вторая группа кинжалов с нарочито длинным навершием (более 85 мм) - это уже рассматривавшиеся кинжалы с широким треугольным клинком [Обыденнов, Савельев, 1994, рис. 2,25,30; Исмагилов, 2001, № 21; Денисов, 2010, рис. 3,3], часть из них - с широкими парными (в основном - дуговидными) долами [Обыденнов, Савельев, 1994, рис. 2,5, 3,28; Исмагилов, 2001, № 45, 46; Денисов, 2010, рис. 3,2$]$, в том числе с дополнительным расширением клинка [Исмагилов, 2001, №22, 39, $41,48]$. В ряде случаев на широких треугольных клинках с расширением в середине или верхней трети долы отсутствуют [Обыденнов, Савельев, 1994, рис. 2,14, 3,24]. Фактически можно говорить о существовании серии кинжалов сложившейся «среднесарматской» формы, но имеющих навершие, характерное для одной очень устойчивой группы прохоровского клинкового оружия. Также и А.В. Симоненко, описывая сарматское оружие Северного Причерноморья, считает, что длинное, плавно изогнутое серповидное навершие является признаком поздних (II-I вв. до н.э.) прохоровских клинков [Симоненко, 2010, с. 23].

В этом отношении показательны четыре случая. На кинжалах из Качеганово, Белебеевского педагогического училища и погр. 4 кург. «б» могильника Прохоровка концы серповидных наверший длиной 1,5-2 см загнуты под углом $180^{\circ}$ (то есть плотно прижаты к самому навершию) [Таиров, 2018, рис. 4; Исма- гилов, 2001, табл. VI,57; Яблонский, 2010, c. 51 , рис. 69,1$]$. На кинжале из Каиндинских песков (Западный Казахстан, центральная часть Чингирлауского района, 50 км к югу от p. Илек) загнутые окончания к навершию плотно не примыкают [Железчиков, 1980, с. 37, рис. 2,6]. Длина наверший с учетом загнутой части у них составляет 11-12 cм, что практически не отличается от длины навершия кинжала из Турсугали. Все эти клинки имеют треугольную форму (из Качеганово - с расширением в верхней трети и узким жалом на окончании) с узкими долами треугольного сечения ${ }^{4}$, то есть они являются дальнейшей стадией развития кинжалов с широким треугольным клинком и широкими же дуговидными долами. Вероятно, многочисленные для Южного Приуралья клинки с «разомкнутым кольцевидным» навершием являются позднепрохоровской «стилизацией» под новую моду распространяющиеся со II-I вв. до н.э. кинжалы с кольцевидным навершием [Скрипкин, 2006 , с. 8-13; 2017, с. 82-83]. Кинжал же из д. Турсугали показывает наличие и противоположной закономерности, когда к новой форме добавлялось традиционное (и, вероятно, значимое для данного общества) серповидное навершие. Несомненно, что все эти случаи могут рассматриваться через призму взаимодействия различных, но при этом в целом синхронных «оружейных традиций» [Симоненко, 2010, c. 32].

Все публикуемые экземпляры относятся к развитому этапу прохоровской (раннесарматской) культуры и датируются III-II вв. до н.э. Выделяемые ранняя и поздняя группы достаточно условны и, возможно, являются не хронологическими, а технологическими, то есть по времени эти клинки могли сосуществовать. Сохранность и условия нахождения (известны для половины публикуемых клинков) однозначно свидетельствуют об их происхождении не из погребальных памятников, а об отнесении к категории «случайных» находок [Савельев, 2016]. Об использовании данных кинжалов в ритуальной деятельности свидетельствуют и следы преднамеренной порчи, фиксируемые на пяти предметах. В двух случаях полностью отломано навершие (рис. 3,4 , $4,2)$, в трех случаях - отломана одна антенна серповидного навершия (рис. $3,3,4,1,3$ ), из них 
в двух случаях это сопровождалось обламыванием кончика клинка (рис. 3,3, 4,1). Данные закономерности ранее были прослежены для всего Южного Приуралья [Савельев, 2016, с. 248-249, рис. 2], в рассматриваемом же случае важно получение идентичной информации по одной локальной территории.

Размеры этой водораздельной территории, выше названной Толбазинским микрорайоном, составляют около $15 \times 15$ км, она окружена со всех сторон реками и имеет узкий, не более 1,5-2 км шириной, проход с юга (рис. 1). Судя по имеющимся данным, находки приурочены к истокам малых водотоков на водораздельных вершинах, а также к долине р. Турсугали. Используя ранее предложенные термины, данная территориальная группа находок кочевнического клинкового оружия может быть названа «кочевой волостью», длительно используемой летней кочевкой (летовочным комплексом) [Савельев, 2018, с. 29; Николаев, Савельев, 2019, с. 203] или же отдельной сотой территории расселения ранних кочевников [Николаев, 2019]. Ближайшие известные соты находятся непосредственно к востоку (Куезбашево-Бишкаин - учтено 8 находок) [Савельев, 2016, табл. 1, рис. 1; Николаев, 2019], в 5-6 км к югу (Месели - учтено 25 находок), в 7-8 км к юго-западу, на истоках р. Турсугали (Шеверли-Шланлы - не менее 5-6 находок), в 12 км к северу (Тукаево учтено 4 находки) [Савельев, 2016, табл. 1, c. $245-248]$.

Здесь очень уместно привести данные из монгольской этнографии: «Поскольку кочевки всегда были ограничены определенными этническими, политическими, а внутри последних еще и административными границами - хотя и условными, и довольно размытыми, - то все сезонные стойбища из года в год располагались, как правило, в одних и тех же местах. Эти места выбирались по принципу максимальных удобств, которые имелись в данной ландшафтной зоне: наличие воды (рек, ручьев, источников, искусственных колодцев), горы или скалы, у подножия которых можно поставить юрту, хорошего пастбища, урочища или ложбины, где можно укрыть в непогоду скот, и т. д.» [Жуковская, 2002, с. 27]. Напомним, что урочище, в котором найден кинжал из Алексеевки (рис. 3,1,6), имеет местное название Елей-Джайляу (баш. - «Хорошая летовка»), то есть данные по кочевникам Монголии вполне применимы и для Южного Урала.

Имеющиеся находки позволяют говорить о том, что освоение кочевниками Бельско-Уршакского водораздела к северу от широты с. Толбазы началось только с III в. до н.э. Вероятно, это расширение на север пределов «кочевой степи» было связано с нарастающей аридизацией в степной зоне и трансформацией ландшафтов лесостепного Приуралья [Савельев и др., 2018]. С этими же процессами связано возникновение и функционирование таких крупных курганных некрополей как Старые Киишки и Бишунгарово, которые расположены в 50-55 км севернее Толбазинского летовочного комплекса и одновременны ему.

\section{ПРИМЕЧАНИЯ}

${ }^{1}$ Гребень водораздела находится в нескольких километрах восточнее описываемой территории. В его пределах, около сел Куезбашево и Бишкаин, также найдены образцы клинкового оружия ранних кочевников (III-І вв. до н.э.) [Николаев, 2019].

2 Данный населенный пункт найден только на карте 1946 г. (масштаб 1 : 200 000). На более поздних и современных картах на его месте обозначена молочная ферма.

3 Анализ выборки, опубликованной Р.Б. Исмагиловым в 2001 г. позволяет включить в серию «кинжалов с гофрированными клинками» еще 3 экземпляра - из Сосновки, Марьевки и Новотроицкого [Исмагилов, 2001, № 22, 95, 124].

${ }^{4}$ Сохранность кинжала из Прохоровки не позволяет четко определить наличие или отсутствие долов на клинке. 


\section{ИЛЛЮСТРАЦИИ}

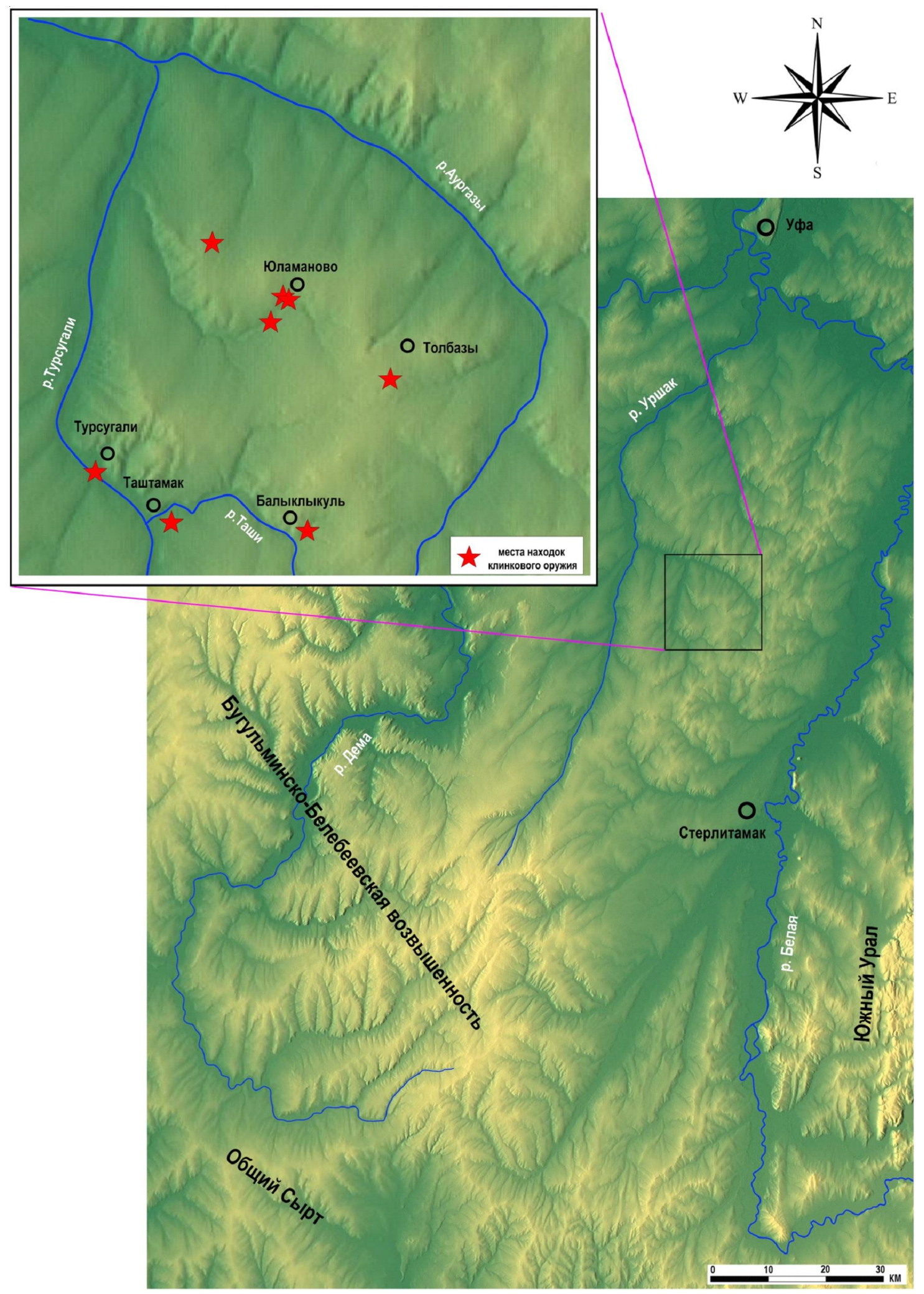

Рис. 1. Южное Приуралье. Расположение Толбазинского микрорайона и места находок кочевнического клинкового оружия

Fig. 1. Southern Urals. Location of the Tolbazinsky microdistrict and finds of nomadic blade weapons 


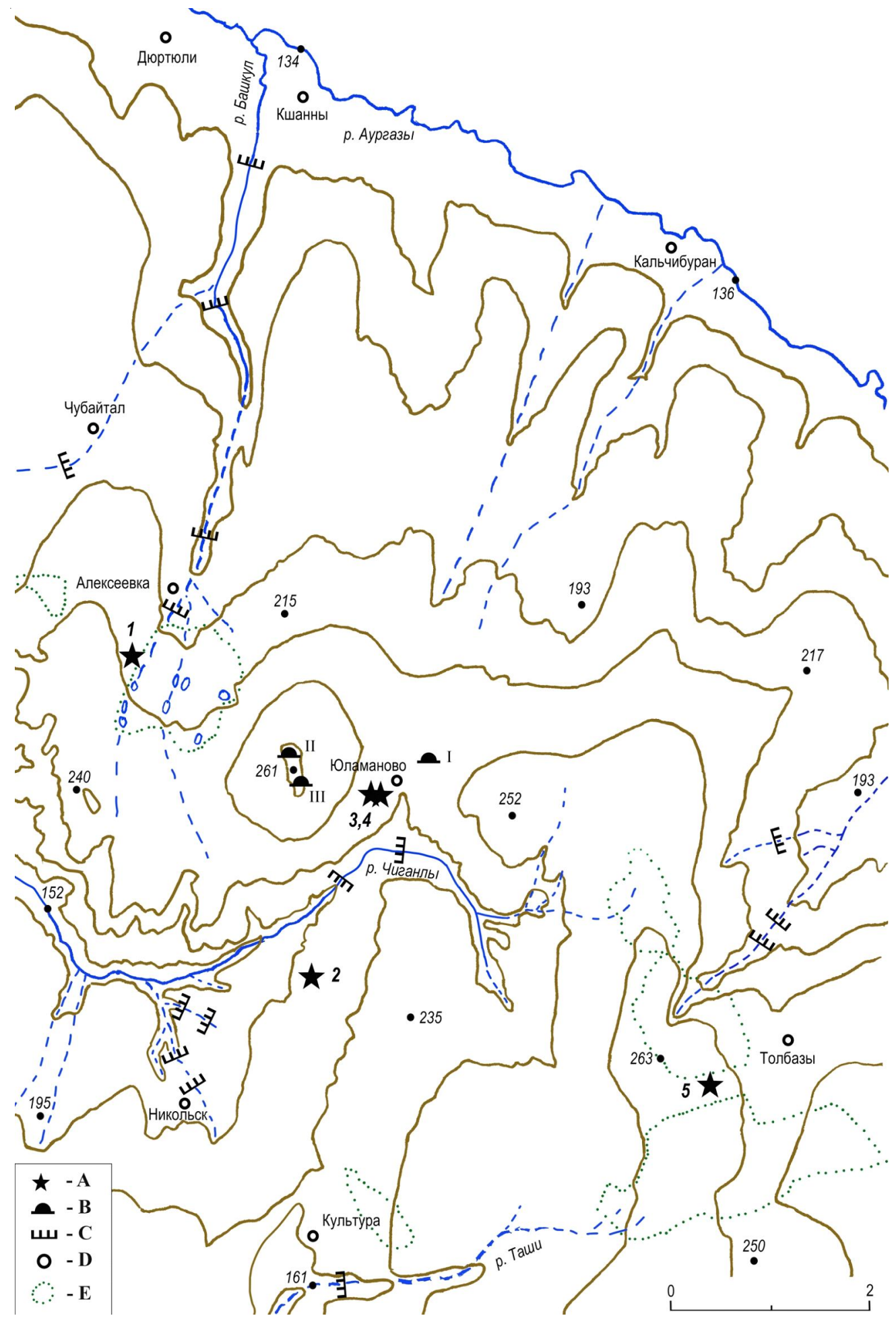

Рис. 2. Толбазинский микрорайон (центральная часть). Находки кочевнического клинкового оружия: $A$ - Алексеевка (1), Куганак (2), Юламаново $(3,4)$, Толбазы (5);

$B$ - курганы Юламановского могильника (I-III-курганы); $C$ - дамбы на малых водотоках; $D$ - современные населенные пункты; $E$ - лесные массивы. На основе карты масштаба 1:25000

Fig. 2. Tolbazinsky microdistrict (central part). Finds of a nomadic blade weapon:

$A$ - Alekseyevka (1), Kuganak (2), Yulamanovo (3, 4); Tolbazy (5);

$B$ - kurgans of the Yulamanovsky kurgan cemetery; $C$ - dams on small streams; $D$ - modern settlements; $E$ - forests. Based on a map of scale 1:25000 


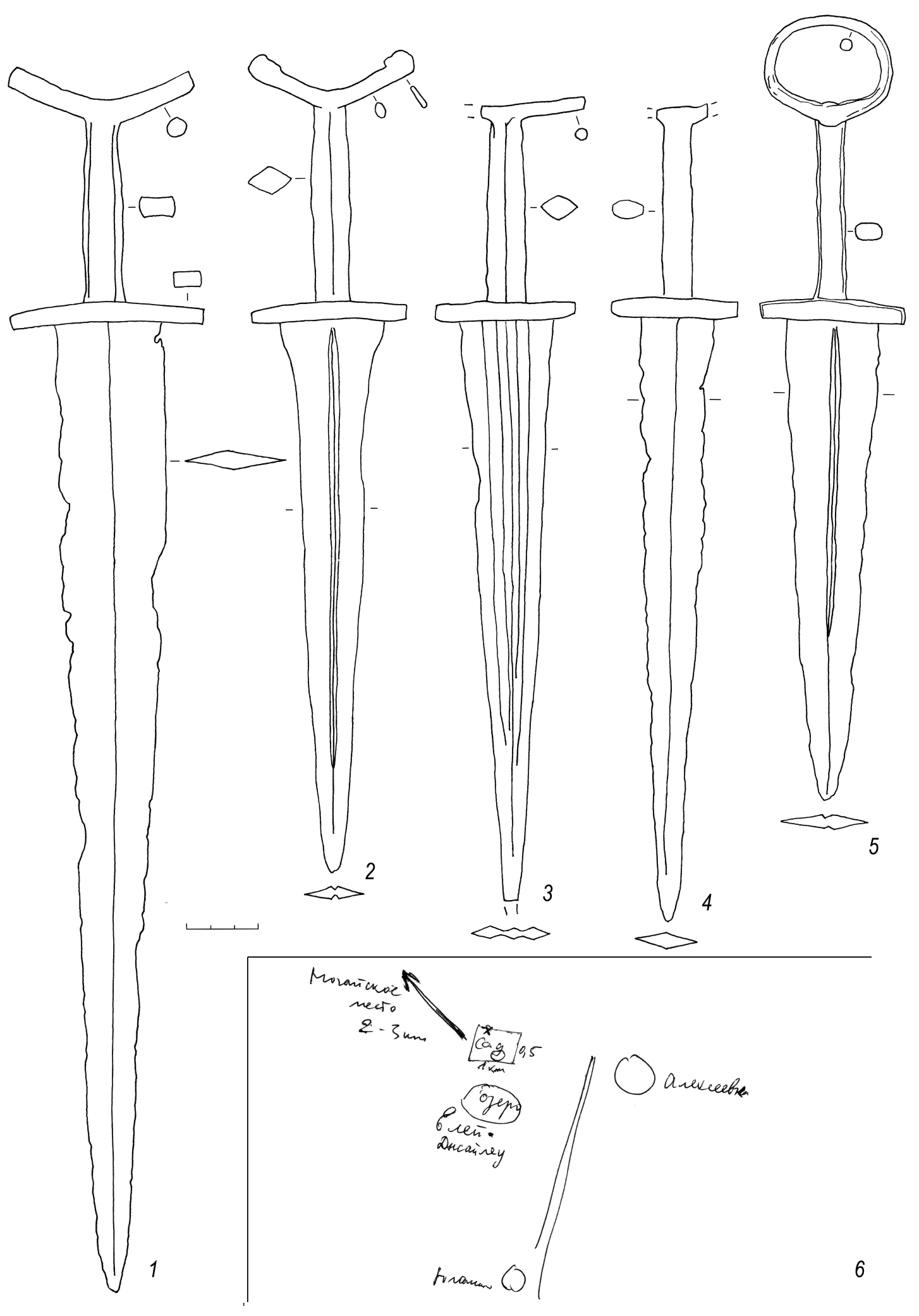

Рис. 3. Толбазинский микрорайон (центральная часть). Находки кочевнического клинкового оружия: 1 - Алексеевка; 2 - Куганак; 3, 4 - Юламаново; 5 - Толбазы;

6 - место находки кинжала из Алексеевки (схема Р.Б. Исмагилова, 1977 г.)

Fig. 3. Tolbazinsky microdistrict (central part). Finds of a nomadic blade weapon:

1 - Alekseyevka; 2 - Kuganak; 3, 4- Yulamanovo; 5 - Tolbazy;

6 - the place where the dagger was found from Alekseyevka (scheme by R. B. Ismagilov, 1977) 
Н.С. Савельев, С.Ю. Николаев. Комплекс сарматских кинжалов из окрестностей с. Толбазы

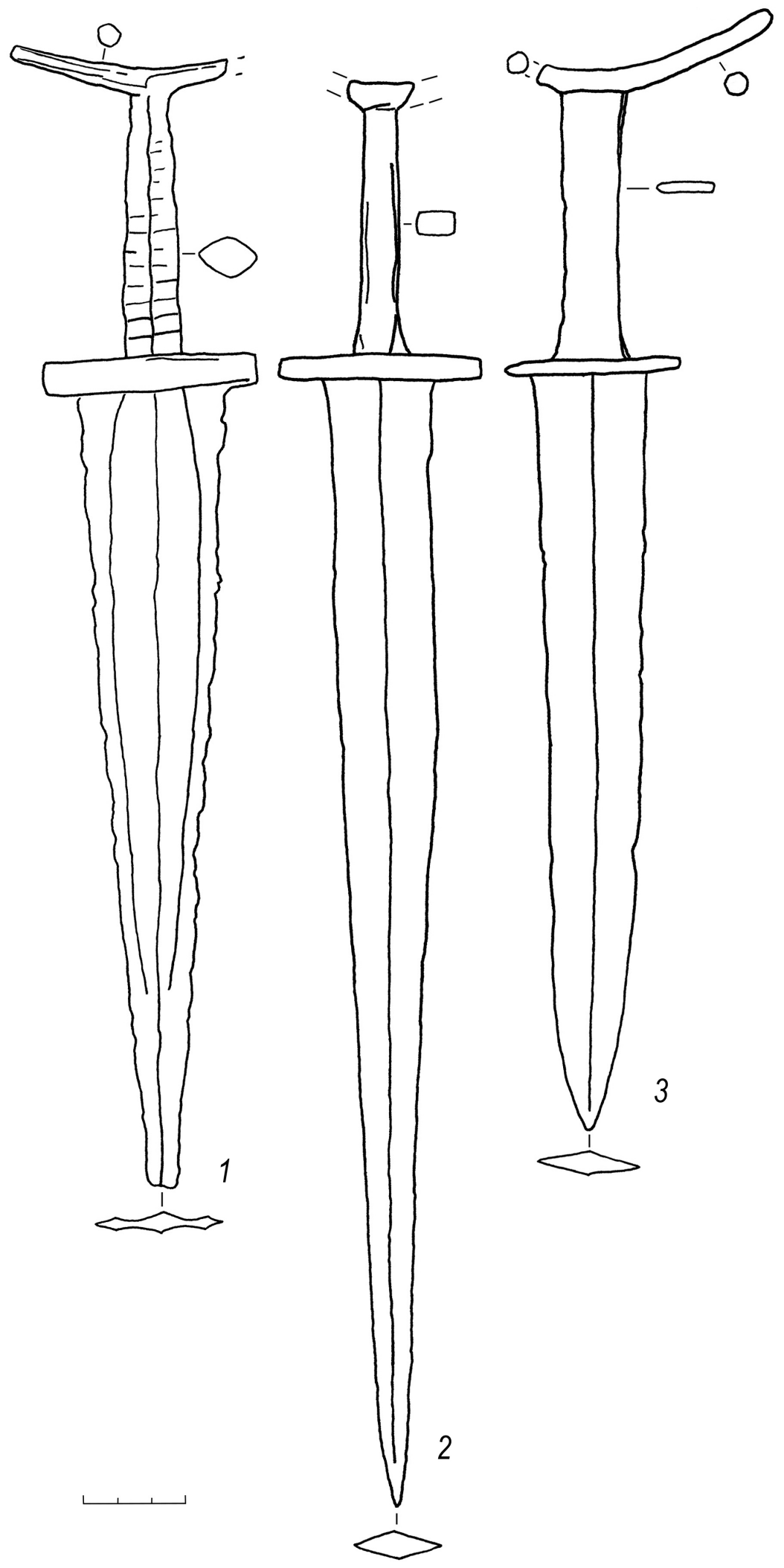

Рис. 4. Толбазинский микрорайон (южная часть). Находки кочевнического клинкового оружия: 1 - Балыклыкуль; 2 - Таштамак; 3 - Турсугали

Fig. 4. Tolbazinsky microdistrict (southern part). Finds of a nomadic blade weapon: 1 - Balyklykul; 2 - Tashtamak; 3 - Tursugali 


\section{СПИСОК ЛИТЕРАТУРЫ}

Археологическая карта Башкирии, 1976. М. : Наука. 264 с.

Горбунов В. С., Исмагилов Р. Б., 1976. Новые находки мечей и кинжалов савромато-сарматского времени в Башкирии // Советская археология. № 3. С. 229-247.

Денисов А. В., 2010. Случайные находки клинкового оружия раннего железного века с территории Самарского Поволжья // 40 лет Средневолжской археологической экспедиции. Краеведческие записки. Вып. 15. Самара: Офорт. С. 222-230.

Железчиков Б. Ф., 1980. Материалы из раскопок П.С. Рыкова в 1927 г. на территории Уральской области // КСИА. ВЫп. 162. С. 32-38.

Жуковская Н. Л., 2002. Кочевники Монголии: Культура. Традиции. Символика : учеб. пособие. М. : Восточная литература. $247 \mathrm{c}$.

Золотые олени Евразии. Каталог выставки, 2001. СПб. : Славия. 248 с.

Исмагилов Р. Б., 1978. Кинжалы позднесавроматского времени из Башкирии // Советская археология. № 4. C. $229-238$.

Исмагилов Р. Б., 1980. Приуральские акинаки с навершием в виде ушастого грифона и хищного животного // Советская археология. № 1. С. 219-227.

Исмагилов Р. Б., 2001. Клинковое оружие эпохи ранних кочевников из Южного Приуралья (случайные находки) // Уфимский археологический вестник. Вып. 3. С. 117-147.

Исмагилов Р. Б., Скарбовенко В. А., 1977. Новые находки савроматского оружия в междуречье Волги и Урала // Средневолжская археологическая экспедиция. Куйбышев : Куйбышевский государственный университет. С. 77-92.

Коллекции Филипповских курганов из фондов Музея археологии и этнографии ИЭИ УФИЦ РАН, 2018. Уфа : Китап. 400 c.

Краева Л. А., Шутелева И. А., Щербаков Н. Б., 2008. Новые находки акинаков в Башкирском Приуралье // Случайные находки: хронология, атрибуция, историко-культурный контекст : материалы тематической науч. конф. (г. Санкт-Петербург, 16-19 декабря 2008 г.). СПб. : Исторический факультет СПбГУ. С. 119-122.

Куринских О. И., 2012. Клинковое оружие ранних кочевников V-I вв. до н.э. из могильников у с. Покровка (Левобережье Илека) // Российская археология. № 2. С. 72-80.

Мордвинцева В. И., Шинкарь О. А., 1999. Сарматские парадные мечи из фондов Волгоградского областного краеведческого музея // Нижневолжский археологический вестник. Вып. 2. С. 138-148.

Николаев С. Ю., 2019. Комплекс сарматского клинкового оружия из окрестностей сел Куезбашево и Бишкаин в Южном Приуралье // У фимский археологический вестник. Вып. 19. С. 69-77.

Николаев С. Ю., Савельев Н. С., 2019. Сарматские кинжалы из окрестностей д. Юламаново в Южном Приуралье // Урал-Алтай: через века в будущее : материалы VIII Всерос. тюркологической конф. (с междунар. участием). Уфа : ИИЯЛ УФИЦ РАН. С. 199-203.

Обыденнов М. Ф., Савельев Н. С., 1994. Оружие ранних кочевников: новые находки в Башкортостане // Вооружение и военное дело древних племен Южного Урала. Уфа : ПКФ Конкорд-Инвест. С. 100-115.

Овсянников В. В., Савельев Н. С., 2019. Воинское святилище на Акбердинском II городище // Археология Евразийских степей. № 2. С. 201-226.

Пшеничнюк А. Х., 2012. Филипповка: некрополь кочевой знати IV века до н.э. на Южном Урале. Уфа : ИИЯЛ УНЦРАН. $280 \mathrm{c}$.

Савельев Н. С., 2016. Мечи и кинжалы в культовой практике кочевников Южного Приуралья скифо-сарматского времени (пространственный анализ «случайных» находок) // Константин Федорович Смирнов и современные проблемы сарматской археологии : материалы IX Междунар. науч. конф. «Проблемы сарматской археологии и истории». Оренбург : Изд-во ОГПУ. С. 241-253.

Савельев Н. С., 2018. Находки мечей и кинжалов скифо-сарматского времени из юго-западных предгорий Южного Урала (к вопросу об освоении территории и особенностях расселения кочевников) // Oriental Studies. Vol. 38. Iss. 4. P. 24-31. DOI: https://doi.org/10.22162/2619-0990-2018-37-3-24-31.

Савельев Н. С., Курманов Р. Г., Сулейманов Р. Р., 2018. Первые результаты комплексных исследований Шиповского городища в лесостепи Южного Приуралья // XXI Уральское археологическое совещание, посвящен- 
ное 85-летию со дня рождения Г.И. Матвеевой и 70-летию со дня рождения И.Б. Васильева : материалы Bсерос. науч. конф. с междунар. участием. Самара : Изд-во СГСПУ. С. 242-244.

Садыкова М. Х., Васильев В. Н., 2001. Поздние прохоровцы в центральной Башкирии // Уфимский археологический вестник. Вып. 3. С. 55-80.

Самашев 3., Кушербаев К., Аманшаев Е., Астафьев А., 2007. Сокровища Устюрта и Манкыстау. Алматы : Археология. $400 \mathrm{c}$.

Симоненко А. В., 2010. Сарматские всадники Северного Причерноморья. СПб. : СПбГУ. 328 с.

Скрипкин А. С., 2006. К проблеме соотношения ранне- и среднесарматской культур // Раннесарматская и среднесарматская культуры: проблемы соотношения : материалы семинара Центра изучения истории и культуры сарматов. Вып. І. Волгоград : Волгоградское научное издательство. С. 5-36.

Скрипкин А. С., 2017. Сарматы. Волгоград : Изд-во ВолГУ. 293 с.

Смирнов К. Ф., Петренко В. Г., 1963. Савроматы Поволжья и Южного Приуралья. САИ. Вып. Д1-9. М. : Изд-во АНСССР. 40 с. +30 табл.

Таиров А. Д., 2018. Кинжалы сарматского времени из Миякинского района Республики Башкортостан // Наука ЮУрГУ : материалы 70-й науч. конф. Секции социально-гуманитарных наук. Челябинск : ЮУрГУ. С. 287-294.

Федоров В. К., 2013. Кинжал из Талалаевки и «савроматские» элементы в оформлении рукоятей прохоровских клинков // Нижневолжский археологический вестник. Вып. 13. С. 33-47.

Хазанов А. М., 1971. Очерки военного дела сарматов. М. : Наука. 171 с.

Яблонский Л. Т., 1998. Работы комплексной Илекской экспедиции на юге Оренбургской области // Археологические памятники Оренбуржья. Вып. 2. Оренбург : Димур. С. 97-119.

Яблонский Л. Т., 2010. Прохоровка. У истоков сарматской археологии. Материалы и исследования по археологии России. № 12. М. : Таус. 383 с.

\section{REFERENCES}

Arkheologicheskaya karta Bashkirii [Archaeological Map of Bashkiria], 1976. Moscow, Nauka Publ. 264 p.

Gorbunov V.S., Ismagilov R.B., 1976. Novye nahodki mechey i kinzhalov savromato-sarmatskogo vremeni v Bashkirii [New Finds of Swords and Daggers of the Sauromatian-Sarmatian Time in Bashkiria]. Sovetskaya arkheologiya [Soviet Archaeology], no. 3, pp. 229-247.

Denisov A.V., 2010. Sluchaynye nahodki klinkovogo oruzhiya rannego zheleznogo veka s territorii Samarskogo Povolzh'ya [Random Finds of Blade Weapons of the Early Iron Age from the Territory of the Samara Volga Region]. 40 let Srednevolzhskoy arkheologicheskoy ekspedicii. Kraevedcheskie zapiski [40 Years of the Middle Volga Archaeological Expedition: Local History Notes], iss. 15. Samara, Ofort Publ., pp. 222-230.

Zhelezchikov B.F., 1980. Materialy iz raskopok P.S. Rykova v 1927 g. na territorii Ural'skoy oblasti [Materials from the Excavations of P.S. Rykov in 1927 in the Ural Region]. Kratkie soobshcheniya Instituta arkheologii AN SSSR [Brief Reports of the Institute of Archaeology of the USSR Academy of Sciences], iss. 162, pp. 32-38.

Zhukovskaya N.L., 2002. Kochevniki Mongolii: Kul'tura. Traditsii. Simvolika: ucheb. posobie [Nomads of Mongolia: Culture. Traditions. Symbolics: Textbook]. Moscow, Vostochnaya literatura Publ. 247 p.

Zolotye oleni Evrazii: Katalog vystavki [Golden Deer of Eurasia: Exhibition Catalog], 2001. Saint Petersburg, Slaviya Publ. 248 p.

Ismagilov R.B., 1978. Kinzhaly pozdnesavromatskogo vremeni iz Bashkirii [Daggers of the Late Sauromatian Period from Bashkiria]. Sovetskaya arkheologiya [Soviet Archaeology], no. 4, pp. 229-238.

Ismagilov R.B., 1980. Priural'skie akinaki s navershiem v vide ushastogo grifona i hishchnogo zhivotnogo [The Akinaks with the Top in the Shape of a Hig-Eared Gryphon and a Beast of Prey from the Ural Region]. Sovetskaya arkheologiya [Soviet Archaeology], no. 1, pp. 219-227.

Ismagilov R.B., 2001. Klinkovoe oruzhie epohi rannih kochevnikov iz Yuzhnogo Priural'ya (sluchaynye nahodki) [Bladed Weapons of the Early Nomadic Period from the Southern Cis-Urals (Accidental Findings)]. Ufimskiy arkheologicheskiy vestnik [The Ufa Archaeological Herald], iss. 3, pp. 117-147. 
Ismagilov R.B., Skarbovenko V.A., 1977. Novye nahodki savromatskogo oruzhiya v mezhdurech'e Volgi i Urala [Sauromatian Weapons: New Findings from the Volga and Ural Interfluve Region]. Srednevolzhskaya arkheologicheskaya ekspediciya [Middle Volga Archaeological Expedition]. Kuibyshev, Kuibyshev State University, pp. 77-92.

Kollektsii Filippovskih kurganov iz fondov Muzeya arkheologii $i$ etnografii IEI UFIC RAN [Collections of Filippovka Kurgans from the Funds of the Museum of Archeology and Ethnography of CER USC RAS], 2018. Ufa, Kitap Publ. 400 p.

Kraeva L.A., Shuteleva I.A., Shcherbakov N.B., 2008. Novye nahodki akinakov v Bashkirskom Priural'e [New Findings of the Akinakas in the Bashkir Cis-Urals]. Sluchaynye nahodki: hronologiya, atributsiya, istorikokul 'turnyy kontekst: materialy tematicheskoy nauch. konf. [Random Finds: Chronology, Attribution, Historical and Cultural Context. Materials of the Thematic Scientific Conference]. Saint Petersburg, St. Petersburg State University, pp. 119-122.

Kurinskih O.I., 2012. Klinkovoe oruzhie rannih kochevnikov V-I vv. do n.e. iz mogil'nikov u s. Pokrovka (Levoberezh'e Ileka) [Early Nomad Blade Weapons from the $6^{\text {th }}-1^{\text {st }} \mathrm{cc}$. BC in the Cemeteries near Pokrovka (Left Bank of the Ilek)]. Rossiyskaya arkheologiya [Russian Archaeology], no. 2, pp. 72-80.

Mordvinceva V.I., Shinkar' O.A., 1999. Sarmatskie paradnye mechi iz fondov Volgogradskogo oblastnogo kraevedcheskogo muzeya [The Sarmatian Parade Daggers Keeping in Volgograd Museum of Local Lore]. Nizhnevolzhskiy arkheologicheskiy vestnik [The Lower Volga Archaeological Bulletin], iss. 2, pp. 138-148.

Nikolaev S.Yu., 2019. Kompleks sarmatskogo klinkovogo oruzhiya iz okrestnostey sel Kuezbashevo i Bishkain v Yuzhnom Priural'e [A Complex of Sarmatian Bladed Weapons from the Vicinity of the Villages of Kuezbashevo and Bishkain in the Southern Cis-Urals]. Ufimskiy arkheologicheskiy vestnik [The Ufa Archaeological Herald], iss. 19, pp. 69-77.

Nikolaev S.Yu., Savelev N.S., 2019. Sarmatskie kinzhaly iz okrestnostey d. Yulamanovo v Yuzhnom Priural'e [Sarmatian Daggers from the Vicinity of the Village of Yulamanovo in the Southern Cis-Urals]. Ural-Altay: cherez veka v budushchee: materialy VIII Vserossiiskoy tyurkologicheskoy konferentsii (s mezhdunarodnym uchastiem) [Ural-Altai: through Centuries to the Future: Materials of the VIII All-Russian Turkological Conference (with International Participation)]. Ufa, IHLL USC RAS, pp. 199-203.

Obydennov M.F., Savelev N.S., 1994. Oruzhie rannih kochevnikov: novye nahodki v Bashkortostane [Weapons of the Early Nomads: New Findings from Bashkortostan]. Vooruzhenie i voennoe delo drevnih plemen Yuzhnogo Urala [Armament and Military Affairs of the Ancient Tribes of the Southern Urals]. Ufa, PKF Konkord-Invest Publ., pp. 100-115.

Ovsyannikov V.V., Savelev N.S., 2019. Voinskoe svyatilishche na Akberdinskom II gorodishche [Military Sanctuary in Akberdino II Settlement]. Arkheologiya Evraziyskih stepey [Archaeology of the Eurasian steppes], no. 2, pp. 201-226.

Pshenichnyuk A.H., 2012. Filippovka: nekropol'kochevoy znati IV veka do n.e. na Yuzhnom Urale [Philippovka: Necropolis of the Nomadic Nobility of the $4^{\text {th }}$ Century BC in the South Urals]. Ufa, IHLL USC RAN. 280 p.

Savelev N.S., 2016. Mechi i kinzhaly v kul'tovoy praktike kochevnikov Yuzhnogo Priural'ya skifo-sarmatskogo vremeni (prostranstvennyy analiz «sluchaynyh» nahodok) [Swords and Daggers in Religious Practices of Southern Urals Nomads from Skythian-Sarmatian Time (Spatial Analysis of 'Accidental' Finds)]. Konstantin Fedorovich Smirnov i sovremennye problemy sarmatskoy arkheologii: materialy IX Mezhdunar. nauch. konf. «Problemy sarmatskoy arkheologii i istorii» [Konstantin Fedorovich Smirnov and Modern Problems of Sarmatian Archaeology. Proceedings of the IX International Scientific Conference "Problems of Sarmatian Archaeology and History"]. Orenburg, Orenburg State Pedagogical University, pp. 241-253.

Savelev N.S., 2018. Nahodki mechey i kinzhalov skifo-sarmatskogo vremeni iz yugo-zapadnyh predgoriy Yuzhnogo Urala (k voprosu ob osvoenii territorii i osobennostyah rasseleniya kochevnikov) [Swords and Daggers of the Scytho-Sarmatian Period: Finds from Southwestern Foothills of the Southern Ural (Development of the Territory and Dispersal of the Nomadic Population Revisited)]. Oriental Studies, vol. 38, iss. 4, pp. 24-31. DOI: https://doi.org/10.22162/2619-0990-2018-37-3-24-31.

Savelev N.S., Kurmanov R.G., Suleymanov R.R., 2018. Pervye rezul'taty kompleksnyh issledovaniy Shipovskogo gorodishcha v lesostepi Yuzhnogo Priural'ya [The First Results of Comprehensive Research of the Shipovsky Settlement in the Forest-Steppe of the Southern Cis-Urals]. XXI Ural'skoe arkheologicheskoe soveshchanie, posvyashch. 85-letiyu so dnya rozhdeniya G.I. Matveevoy i 70-letiyu so dnya rozhdeniya I.B. Vasil'eva: materialy Vseros. nauch. konf. s mezhdunar. uchastiem [XXI Ural Archaeological Meeting Dedicated to the 
$85^{\text {th }}$ Anniversary of the Birth of G.I. Matveeva and the $70^{\text {th }}$ Anniversary of the Birth of I.B. Vasiliev. Materials of the All-Russian Scientific Conference with International Participation]. Samara, Samara State Social and Pedagogical University, pp. 242-244.

Sadykova M.H., Vasil'ev V.N., 2001. Pozdnie prohorovtsy v central'noy Bashkirii [Nomads of the Late Stage of the Prokhorov Archaeological Culture in Central Bashkiriya]. Ufimskiy arkheologicheskiy vestnik [The Ufa Archaeological Herald], iss. 3, pp. 55-80.

Samashev Z., Kusherbaev K., Amanshaev E., Astaf'ev A., 2007. Sokrovishcha Ustyurta i Mankystau [Treasures of Ustyurt and Mankystau]. Almaty, Arkheologiya, 400 p.

Symonenko A.V., 2010. Sarmatskie vsadniki Severnogo Prichernomor'ya [Sarmatian Horsemen of North Pontic Region]. St. Petersburg, St. Petersburg State University. 328 p.

Skripkin A.S., 2006. K probleme sootnosheniya ranne- i srednesarmatskoy kul'tur [To the Problem of Correlation of Early and Middle Sarmatian Cultures]. Rannesarmatskaya i srednesarmatskaya kul'tury: problemy sootnosheniya: materialy seminara Centra izucheniya istorii $i$ kul 'tury sarmatov [Early and Middle Sarmatian Cultures: Problems of Correlation. Materials of the Seminar of the Center for the Study of Sarmatian History and Culture], iss. 1. Volgograd, Volgograd Scientific Publishing House, pp. 5-36.

Skripkin A.S., 2017. Sarmaty [Sarmatians]. Volgograd, Volgograd State University. 293 p.

Smirnov K.F., Petrenko V.G., 1963. Savromaty Povolzh'ya i Yuzhnogo Priural'ya [Sauromats of the Volga and Southern Urals]. Svod arkheologicheskih istochnikov, iss. Д1-9. Moscow, AS SSSR. 40 p.

Tairov A.D., 2018. Kinzhaly sarmatskogo vremeni iz Miyakinskogo rayona Respubliki Bashkortostan [Daggers of Sarmatian Time from the Miyakinsky District of the Republic of Bashkortostan]. Nauka YuUrGU: materialy 70-y nauch. konf. Sektsii social'no-gumanitranyh nauk [Science of SUSU. Materials of the 70 ${ }^{\text {th }}$ Scientific Conference. Sections of Social Sciences and Humanities]. Chelyabinsk, South Ural State University, pp. 287294.

Fyodorov V.K., 2013. Kinzhal iz Talalaevki i «savromatskie» elementy v oformlenii rukoyatey prohorovskih klinkov [Dagger from Talalayevka and "Sauromatic" Elements in the Ornamentation of Handles of Prokhorovsky Type Blade Weapons]. Nizhnevolzhskiy arkheologicheskiy vestnik [The Lower Volga Archaeological Bulletin], iss. 13, pp. 33-47.

Khazanov A.M., 1971. Ocherki voennogo dela sarmatov [Essays on Military Affairs of the Sarmatians]. Moscow, Nauka Publ. 171 p.

Yablonskiy L.T., 1998. Raboty kompleksnoy Ilekskoy ekspeditsii na yuge Orenburgskoy oblasti [Proceedings of the Complex Ilek Expedition in the South of the Orenburg Region]. Arkheologicheskie pamyatniki Orenburzh'ya [Archaeological Sites of Orenburg Region], iss. 2. Orenburg, Pechatnyy dom «Dimur» Publ., pp. 97-119.

Yablonskiy L.T., 2010. Prohorovka. U istokov sarmatskoy arkheologii [Prokhorovka. At the Origins of Sarmatian Archaeology]. Materialy I issledovaniya po arkheologii Rossii, no. 12. Moscow, Taus Publ. 383 p. 


\section{Information About the Authors}

Nikita S. Savelev, Candidate of Sciences (History), Associate Professor, Leading Researcher, Department of Archaeological Research, Institute of History, Language and Literature, Ufa Federal Research Center of the Russian Academy of Sciences, Prosp. Oktyabrya, 71, 450054 Ufa, Russian Federation, sns_1971@mail.ru, https://orcid.org/0000-0002-3643-2388

Sergey Yu. Nikolaev, Junior Researcher, Department of Archaeological Research, Institute of History, Language and Literature, Ufa Federal Research Center of the Russian Academy of Sciences, Prosp. Oktyabrya, 71, 450054 Ufa, Russian Federation, nikolaev.sergey123@yandex.ru, https://orcid.org/0000-0003-3350-9148

\section{Информация об авторах}

Никита Сергеевич Савельев, кандидат исторических наук, доцент, ведущий научный сотрудник отдела археологических исследований Института истории, языка и литературы, Уфимский федеральный исследовательский центр РАН, просп. Октября, 71, 450054 г. Уфа, Российская Федерация, sns_1971@mail.ru, https://orcid.org/0000-0002-3643-2388

Сергей Юрьевич Николаев, младший научный сотрудник отдела археологических исследований Института истории, языка и литературы, Уфимский федеральный исследовательский центр РАН, просп. Октября, 71, 450054 г. Уфа, Российская Федерация, nikolaev.sergey123@yandex.ru, https://orcid.org/0000-0003-3350-9148 